\title{
FAKTOR-FAKTOR YANG MEMPENGARUHI KETIDAKCUKUPAN KUNJUNGAN PADA IBU MASA NIFAS DI RUMAH BERSALIN MITRA ANANDA PALEMBANG TAHUN 2020
}

\author{
FACTORS AFFECTING INEQUACY OF VISIT IN THE POST PARTUM \\ IN KLINIC MITRA ANANDA PALEMBANG 2020
}

\author{
Tiara Fatrin ${ }^{1}$,Nica Nova Lia $^{2}$, Yona Sari ${ }^{3}$ \\ Sekolah Tinggi Ilmu Kesehatan Abdurahman Palembang, Sumatera Selatan ${ }^{1,2,3}$ \\ Email : tiarafatrin23.tf@gmail.com ${ }^{1}$,nicanovalia12@gmail.com ${ }^{2}$, Yonaasari@gmail.com ${ }^{3}$
}

\begin{abstract}
ABSTRAK
Masa Nifas (puerperium) adalah masa telah keluarnya plasenta sampai sampai alat-alat reproduksi kembali pulih seperti sebelum hamil dan secara normal masa nifas berlangsung selama 6 minggu atau 40 hari. Tujuan penelitian : Mengetahui faktor -faktor yang mempengaruhi ketidakcukupan kunjungan pada ibu masa nifas. Metode penelitian: Deskriptif analitik dengan pendekatan cross sectional dengan jumlah sampel adalah ibu nifas 6 minggu sebanyak 33 responden, data diambil dengan menggunakan lembar checklist dan quisioner. Analisa data menggunakan uji statistik chi square. Hasil penelitian: dari 33 responden terdapat 23 responden $(69,7 \%)$ yang kunjungan nifasnya cukup dan 10 responden $(30,3 \%)$ tidak cukup, terdapat 23 responden $(69,7 \%)$ berpengetahuan tinggi dan 10 responden $(30,3 \%)$ berpengetahuan rendah, terdapat 21 responden $(63,6 \%)$ berpendidikan tinggi dan 12 responden $(36,4 \%)$ berpendidikan rendah, terdapat 20 responden $(60,6 \%)$ dengan paritas tinggi dan 13 responden $(39,4 \%)$ paritas rendah. Hasil uji statistik chi square diperoleh nilai $p$ value $0,012, p$ value $0,000, p$ value 0,000 . Kesimpulan: ada hubungan yang signifikan antara pengetahuan dengan ketidakcukupan kunjungan pada ibu masa nifas, ada hubungan yang signifikan antara pendidikan dengan ketidakcukupan kunjungan pada ibu masa nifas, ada hubungan yang signifikan antara paritas dengan ketidakcukupan kunjungan pada ibu masa nifas.
\end{abstract}

Kata Kunci: Masa Nifas, Ketidakcukupan Kunjungan

\begin{abstract}
The puerperium is the time when the placenta has been released until the reproductive organs are recovered as before pregnancy, and normally the postpartum period lasts for 6 weeks or 40 days. Study objective: To determine the factors that influenced the insufficient of postpartum checkup of postpartum mothers. Study method: Descriptive analytic with cross sectional approach. The sample was 33 postpartum mothers for 6 weeks puerperium. The data were collected using a checklist and questionnaires. Data analysis used chi square statistical test. Results of the study: 23 respondents (69.7\%) had sufficient postpartum checkup and 10 respondents (30.3\%) were insufficient; 23 respondents $(69.7 \%)$ had high knowledge and 10 respondents $(30.3 \%)$ had low knowledge; there were 21 respondents (63.6\%) with high education and 12 respondents (36.4\%) with low education; there were 20 respondents $(60.6 \%)$ with high parity and 13 respondents $(39.4 \%)$ with low parity. The results of the chi square statistical test obtained $p$ value 0.012, $p$ value 0.000, $p$ value 0.000. Conclusion: there was a significant correlation between knowledge and insufficient postpartum checkup to postpartum mothers, there was a significant correlation between education and insufficient postpartum checkup to postpartum mothers, and there was a significant relationship between parity and insufficient postpartum checkup to postpartum mothers.
\end{abstract}

Keywords:Insufficient of Postpartum Checkup, Puerperium 


\section{PENDAHULUAN}

Masa Nifas (Puerperium) adalah masa setelah keluarnya plasenta sampai alat-alat reproduksi pulih seperti sebelum hamil dan secara normal masa nifas berlangsung selama 6 mingguatau 40 hari ${ }^{1}$. Kunjungan masa nifas dilakukan untuk menilai keadaan ibu dan bayi baru lahir, dan untuk menjaga, mendeteksi dan menangani masalah - masalah yang terjadi, terdapat 4 kali kunjungan yaitu 6-8 jam setelah Persalinan, 6 hari setelah persalinan, 2 minggu setelah persalinan, 6 minggu setelah persalinan ${ }^{2}$.

Masa nifas merupakan masa yang rawan bagi ibu, sekitar $60 \%$ kematian ibu di Indonesia terjadi setelah melahirkan dan hampir $50 \%$ dari kematian pada masa nifas terjadi pada 24 jam pertama setelah persalinan,diantaranya disebabkan oleh adanya komplikasi masa nifas. Jumlah ibu nifas di Indonesia tahun 2015 sebanyak 4,830,609 jiwa dan cakupan kunjungan nifas sebesar $90 \%^{3}$.

Cakupan Pelayanan kunjungan Nifas di Provinsi Sumatera Selatan sampai dengan Bulan Desember 2015 mencapai 91,04\%. Cakupan Pelayanan Nifas di Kabupaten/Kota berkisar antara 85,0\% - 95,3\%. Kunjungan Nifas tahun 2015 mengalami sedikit peningkatan dibandingkan dengan cakupan kunjungan nifas di tahun 2014. Cakupan pelayanankunjungan nifas di Kota Palembang Tahun 2017 mencapai $97,43 \%$, sudah memenuhi target pelayanan minimum yaitu $90 \%{ }^{4}$.

Kunjungan masa nifas sangat dianjurkan pada ibu nifas untuk mengetahui kondisi kesehatannya. Kunjungan masa nifas merupakan kunjungan yang dilakukan ibu nifas ke tenaga kesehatan selama masa nifas yaitu dimulai setelah kelahiran placenta dan berakhir ketika alat-alat kandungan seperti keadaan sebelum hamil, masa nifas berlangsung selam kira-kira 6 minggu 5 .

Beberapa faktor yang dapat mempengaruhi kunjungan masa nifas yaitu faktor predisposisi (pengetahuan, sikap, pendidikan, paritas, kepercayaan, keyakinan, nilai-nilai), faktor pendukung (ketersediaan dan jarak fasilitas kesehatan), faktor pendorong (sikap dan perilaku petugas kesehatan $)^{6}$.

Berdasarkan hasil penelitian faktor yang berhubungan dengan kunjungan nifas diwilayah kerja Puskesmas Jelbuk (Kabupaten Jember,). Pada ibu nifas dapat disimpulkan bahwa terdapat hubungan antara faktor prediposisi (predisposing factors) yang meliputi umur, pengetahuan, sikap dengan kunjungan ibu nifas, dan tidak terdapat hubungan pendidikan dan pekerjaan dengan kunjungan ibu nifas. Terdapat hubungan antara faktor pendukung (enabling factors) yaitu akses kemudahan transportasi dengan kunjungan ibu nifas dan tidak terdapat hubungan antara ketersediaan pelayanan kesehatan, pelayanan petugas dan akses jarak dengan kunjungan ibu nifas. Dan terdapat hubungan antara faktor pendorong (reinforcing faktors)yang meliputi peran bidan, dekungan keluarga, dengan kunjungan ibu nifas ${ }^{7}$.

Tujuan penelitian ini adalah untuk mengetahui faktor-faktor yang mempengaruhi ketidakcukupan kunjungan pada ibu masa nifas.

\section{METODE PENELITIAN}

Metode Penelitian yang digunakan adalah deskriptif analitik yaitu penelitian yang dilakukan dengan tujuan untuk mengetahui hubungan pengetahuan, pendidikan, paritas ibu postpartum terhadap kunjungan masa nifas dengan pendekatan cross sectional. Populasi yang digunakan dalam penelitian ini adalah seluruh ibu postpartum yang berjumlah 62 populasi pada bulan Januari, Februari, dan Maret. 
Sampel yang didapatkan dengan cara non random dengan menggunakan teknik purposive sampling yaitu ibu nifas 6 minggu dengan jumlah 33 sampel, didapat dengan memberikan kuesioner dan checklist kepada responden.

\section{HASIL PENELITIAN}

Analisa Univariat

Kunjungan Nifas

Tabel 1. Distribusi Frekuensi Berdasarkan Kunjungan Nifas

\begin{tabular}{ccc}
\hline Kunjungan Nifas & Frekuensi (f) & Presentase (\%) \\
\hline Cukup & 23 & $69,7 \%$ \\
\hline Tidak Cukup & 10 & $30,3 \%$ \\
\hline Total & 33 & $100 \%$ \\
\hline
\end{tabular}

Berdasarkan Tabel 1 dari 33 responden ibu nifas diperoleh data yang memiliki cakupan kunjungan nifas yang cukup sebanyak 23 responden $(69,7 \%)$, sedangkan ibu nifas
Dikarenakan kondisi yang tidak mendukung (pandemi COVID-19) pada saat penelitian ini dilakukan pembagian quesioner melalui via telepon kepada responden.

\section{Pengetahuan}

Tabel 2. Distribusi Frekuensi Berdasarkan Pengetahuan Ibu

\begin{tabular}{ccc}
\hline Pengetahuan & Frekuensi (f) & Presentase (\%) \\
\hline Tinggi & 23 & $69,7 \%$ \\
\hline Rendah & 10 & $30,3 \%$ \\
\hline Total & 33 & $100 \%$ \\
\hline
\end{tabular}

Berdasarkan tabel 2 dari 33 responden ibu nifas yang memiliki pengetahuan tinggi sebanyak 23 responden $(69,7 \%)$ sedangkan

Pendidikan ibu nifas yang memiliki pengetahuan rendah sebanyak 10 responden $(30,3 \%)$.

Tabel 3. Distribusi Frekuensi Berdasarkan Pendidikan Ibu

\begin{tabular}{ccc}
\hline Pendidikan & Frekuensi (f) & Presentase (\%) \\
\hline Tinggi & 21 & $63,6 \%$ \\
Rendah & 12 & $36,4 \%$ \\
\hline Total & 33 & $100 \%$ \\
\hline
\end{tabular}

Berdasarkan tabel 3 dari 33 responden ibu nifas yang memiliki pendidikan tinggi yang memiliki cakupan kunjungan nifas yang tidak cukup yaitu sebanyak 10 responden $(30,3 \%)$. 
Paritas

Tabel 4. Distribusi Frekuensi Berdasarkan Paritas Ibu

\begin{tabular}{ccc}
\hline Paritas & Frekuensi (f) & Presentase (\%) \\
\hline Tinggi & 20 & $60,6 \%$ \\
Rendah & 13 & $39,4 \%$ \\
\hline Total & 33 & $100 \%$ \\
\hline
\end{tabular}

Berdasarkan tabel 4 dari 33 responden yang $(60,6 \%)$, sedangkan yang memiliki paritas memiliki paritas tinggi yaitu 20 responden rendah yaitu 13 responden $(39,4 \%)$.

Analisa Bivariat

Hubungan Pengetahuan dengan Ketidakcukupan Kunjungan pada Ibu Masa Nifas di RB Mitra Ananda Palembang Tahun 2020

Tabel 5. Hubungan Pengetahuan dengan terhadap Ketidakcukupan Kunjungan Pada Ibu Masa Nifas di BPM Mitra Ananda Palembang Tahun 2020

\begin{tabular}{|c|c|c|c|c|c|c|c|}
\hline \multirow{3}{*}{ Pengetahuan } & \multicolumn{4}{|c|}{ Kunjungan Nifas } & \multirow{2}{*}{\multicolumn{2}{|c|}{ Jumlah }} & \multirow{3}{*}{$P$ Value } \\
\hline & \multicolumn{2}{|c|}{ Cukup } & \multicolumn{2}{|c|}{ Tidak Cukup } & & & \\
\hline & $\mathbf{n}$ & $\%$ & $\mathbf{n}$ & $\%$ & $\mathbf{N}$ & $\%$ & \\
\hline Tinggi & 13 & 39,4 & 10 & 30,3 & 23 & 69,7 & \multirow{3}{*}{0,012} \\
\hline Rendah & 10 & 30,3 & 0 & 0 & 10 & 30,3 & \\
\hline Jumlah & 23 & 69,7 & 10 & 30,3 & 33 & 100 & \\
\hline
\end{tabular}

Berdasarkan tabel 5 hubungan antara pengetahuan dengan ketidakcukupan kunjungan pada ibu masa nifas diperoleh bahwa dari 33 responden yang memiliki pengetahuan tinggi dengan kunjungan nifas cukup yaitu sebanyak 13responden $(39,4 \%)$ sedangkan untuk kunjungan nifas tidak cukup sebanyak 10 responden $(30,3 \%)$. Untuk responden berpengetahuan rendah dengan kunjungan nifas cukup yaitu sebanyak 10 responden $(30,3 \%)$ sedangkan kunjungan nifas tidak cukup sebanyak 0 responden $(0 \%)$. dari hasil tersebut menunjukan bahwa ibu yang pengetahuan tinggi lebih banyak melakukan kunjungan nifas dibandingkan ibu yang berpengetahuan rendah hal ini dapat dilihat dimana ibu menjawab kuesioner yang diberikan.

Hasil analisa uji statistik menggunakan Chi-Square pada penelitian ini mendapatkan nilai $p$ value $0,013(p>\alpha)$ yang menunjukkan derajat hubungan yang sangat kuat. Dari hasil analisa uji statistik tersebut dapat disimpulkan bahwa adanya hubungan yang signifikan antara pengetahuan dengan ketidakcukupan kunjungan pada ibu masa nifas. 
p-ISSN: 2503-1392

e-ISSN: 2620-5424

Hubungan Pendidikan dengan Ketidakcukupan Kunjungan pada Ibu Masa Nifas di RB Mitra Ananda Palembang Tahun 2020

Tabel 6. Hubungan Pendidikan Terhadap Ketidakcukupan Kunjungan Pada Ibu Masa Nifas

\begin{tabular}{cccccccc}
\hline & \multicolumn{9}{c}{ Kunjungan Nifas } & \multirow{2}{*}{ Jumlah } & \multirow{2}{*}{ p. value } \\
\cline { 2 - 7 } Pendidikan & \multicolumn{2}{c}{ Cukup } & \multicolumn{2}{c}{ Tidak Cukup } & & \\
\cline { 2 - 7 } & $\mathbf{n}$ & $\boldsymbol{\%}$ & $\mathbf{n}$ & $\mathbf{\%}$ & $\mathbf{N}$ & $\mathbf{\%}$ & \\
\hline Tinggi & 21 & 63,6 & 0 & 0 & 21 & 63,6 & \multirow{2}{*}{0,000} \\
\hline Rendah & 2 & 6,1 & 10 & 30,3 & 12 & 36,4 & \\
\hline Jumlah & 23 & 69,7 & 10 & 30,3 & 33 & 100 & \\
\hline
\end{tabular}

Berdasarkan tabel 6 yang dilakukan di RB mitra Ananda Palembang tahun 2020 diperoleh bahwa dari 33 responden yang memiliki pendidikan tinggi dengan kunjungan nifas cukup yaitu sebanyak 21 responden $(63,6 \%)$ dan untuk kunjungan nifas tidak cukup sebanyak 0 responden $(0 \%)$. Sedangkan untuk pendidikan rendah dengan kunjungan nifas cukup yaitu sebanyak 2 responden $(6,1 \%)$ dan untuk kunjungan nifas tidak cukup sebanyak 10 responden $(30,3 \%)$.

Didapatkan nilai $p$ value adalah 0,000 yang menunjukkan bahwa adanya hubungan yang bermakna antara pendidikan dengan ketidakcukupan kunjungan pada ibu masa nifas.

Hubungan Paritas dengan Ketidakcukupan Kunjungan pada Ibu Masa Nifas di RB Mitra Ananda Palembang Tahun 2020

Tabel 7. Hubungan Paritas Terhadap Ketidakcukupan Kunjungan Pada Ibu Masa Nifas

\begin{tabular}{|c|c|c|c|c|c|c|c|}
\hline \multirow{3}{*}{ Paritas } & \multicolumn{4}{|c|}{ Kunjungan Nifas } & \multirow{2}{*}{\multicolumn{2}{|c|}{ Jumlah }} & \multirow{3}{*}{$P$ Value } \\
\hline & \multicolumn{2}{|c|}{ Cukup } & \multicolumn{2}{|c|}{ Tidak Cukup } & & & \\
\hline & $\mathbf{N}$ & $\%$ & $\mathbf{N}$ & $\%$ & $\mathbf{N}$ & $\%$ & \\
\hline Tinggi & 20 & 60,6 & 0 & 0 & 20 & 60,6 & \multirow{3}{*}{$\mathbf{0 , 0 0 0}$} \\
\hline Rendah & 3 & 9,1 & 10 & 30,3 & 13 & 39,4 & \\
\hline Jumlah & 23 & 69,7 & 10 & 30,3 & 33 & 100 & \\
\hline
\end{tabular}

Dari hasil penelitian yang dilakukan di RB Mitra Ananda Palembang tahun 2020 diperoleh bahwa dari 33 responden yang memiliki paritas tinggi dengan kunjungan nifas cukup yaitu sebanyak 20 responden $(60,6 \%)$ dan untuk kunjungan nifas tidak cukup sebanyak 0 responden $(0 \%)$. Sedangkan untuk paritas rendah dengan kunjungan nifas cukup yaitu sebanyak 3 responden $(9,1 \%)$ dan kunjungan nifas tidak cukup sebanyak 10 responden $(30,3 \%)$.

Adapun hasil analisa hubungan antara paritas dengan ketidakcukupan kunjungan pada ibu masa nifas dengan menggunakan uji Chi-Square diperoleh nilai $\mathrm{p}$ value 0,000 ( $\mathrm{p}<\alpha)$ yang menunjukkan adanya hubungan yang signifikan antara paritas dengan ketidakcukupan kunjungan pada ibu masa nifas.

\section{PEMBAHASAN}

Analisa Univariat

Kunjungan Nifas

Kunjungan masa nifas sangat dianjurkan pada ibu nifas untuk mengetahui kondisi kesehatannya. Kunjungan masa nifas 
merupakan kunjungan yang dilakukan ibu nifas ketenaga kesehatan selama masa nifas yaitu dimulai setelah kelahiran plasenta dan berakhir ketika alat-alat kandungan seperti keadaan sebelum hamil6, masa nifas ataupun perperium dimulai sejak 1 jam setelah lahirnya plasenta sampai dengan 6 minggu (42 hari) setelah itu. Pelayanan pasca persalinan harus terselenggara pada masa itu. Terdapat 4 kali kunjungan masa nifas: Kunjungan ke-1 (6-8 jam setelah persalinan) tujuanya untuk mencegah perdarahan masa nifas karena atonia uteri, mendeteksi dan merawat penyebab lain perdarahan. Kunjungan ke-2 (6 hari setelah persalinan) tujuanya untuk memastikan involusio uterus berjalan normal, memastikan ibu mendapat cukup makanan, cairan, dan istirahat, memastikan ibu menyusui dengan baik dan tidak memperlihatkan tanda-tanda penyulit, memberikan konseling

Pada ibu mengenai asuhan pada bayi, tali pusat, menjaga bayi tetap hangat dan merawat bayi sehari-hari. Kunjungan ke-3 (2 minggu setelah persalinan) disesuaikan berdasarkan perubahan fisik, fisiologis, dan psikologis yang diharapkan dalam dua minggu pasca partum.

Pada kunjungan nifas ini juga adalah kesempatan terbaik untuk meninjau pilihan kontrasepsi yang ada. Banyak pasangan memilih memulai hubungan seksual segera setelah lokhia ibu menghilang. Kunjungan ke-4 (6 minggu setelah persalinan) Menanyakan pada ibu tentang penyulit-penyulit yang ia atau bayi alami, memberikan konseling untuk keluarga berencana secara dini, imunisasi, senam.. nifas, dan tanda - tanda bahaya yang dialami oleh ibu dan bayi.

Pengetahuan

Pengetahuan merupakan hasil tahu, dan ini terjadi setelah orang melakukan pengindraan terhadap suatu objek tertentu.
Pengindraan terjadi melalui panca indra, yakni indra penglihatan, pendengaran, penciuman, perasa, dan peraba. Sebagian besar pengetahuan manusia diperoleh melalui mata dan telinga8. Pemahaman tentang masa nifas dapat dibagi menjadi 2 yaitu tinggi rendahnya pengetahuan ibu yang dapat dilihat dari berapa persen ibu mengetahui tentang kunjungan masa nifas. Hasil penelitian yang dilakukan9 menyebutkan bahwa ibu yang berpengetahuan baik 1,9 kali berpeluang untuk melakukan kunjungan nifas dibandingkan dengan ibu yang berpengetahuan kurang. Semakin tinggi tingkat pengetahuan, semakin ibu melakukan kunjungan nifas.

Pendidikan

Pendidikan adalah segala upaya yang direncanakan untuk mempengaruhi orang lain baik individu, kelompok, atau masyarakat sehingga mereka melakukan apa yang diharapkan oleh prilaku pendidikan. Tingkat pendidikan ini merupakan salah satu aspek sosial yang dapat mempengaruhi tingkah laku manusia. Pendidikan akan mempengaruhi seseorang dalam melakukan respon terhadap sesuatu yang yang datang dari luar. Orang yang mempunyai pendidikan lebih akan memberikan respon yang lebih rasional10.

Hasil penelitian ini sesuai dengan penelitian yang dilakukan oleh11tentang faktor-faktor yang berhubungan antara pendidikan dengan kunjungan masa nifas, hal ini dikarenakan semakin tinggi pendidikan seseorang maka semakin mudah seseorang menerima informasi/ edukasi tentang kunjungan masa nifas. Dari penelitian ini bahwa pendidikan ibu nifas berhubungan dengan kunjungan masa nifas, karena pendidikan ibu mempengaruhi dalam pemeriksaan masa nifas, semakin tinggi pendidikan yang diperoleh ibu semakin rendah kejadian infeksi dan komplikasi masa nifas. 
Tingkat pendidikan dan akses ibu terhadap media masa juga mempengaruhi pengambilan keputusan, dimana semakin tinggi Pendidikan semakin besar peluang untuk melakukan kunjungan nifas.Tingkat pendidikan formal yang tinggi memang dapat membentuk nilai-nilai progresif pada diri seseorang, terutama dalam menerima hal-hal baru, termasuk pentingnya melakukan kunjungan nifas. Tingkat Pendidikan inilah yang membantu seorang ibu untuk lebih mudah menangkap dan memahami suatu informasi, sehingga lebih mudah mengadopsi pengetahuan baru khususnya mengenai pentingnya kunjungan masa nifas ${ }^{9}$.

Dalam penelitian yang dilakukan ${ }^{9}$ menunjukkan bahwa rendahnya pendidikan dan kurangnya informasi dapat berpengaruh terhadap kegagalan kunjungan masa nifas., menyebutkan semakin tinggi tingkat pendidikan seseorang maka semakin tinggi membutuhkan pusat-pusat pelayanan kesehatan sebagai tempat berobat bagi dirinya dan keluarga. Dengan berpendidikan tinggi, maka wawasan pengetauhan semakin bertambah dan semakin menyadari bahwa kesehatan begitu penting bagi kehidupan sehingga termotivasi untuk melakukan kunjungan ke pusat-pusat pelayanan kesehatan yang lebih baik. Pendidikan menjadi duakategori yaitu pendidikan tinggi ( $\geq \mathrm{SMA} /$ sederajat) dan pendidikan rendah $\left(\leq \mathrm{SMA} /\right.$ sederajat $^{12}{ }^{12}$.

Paritas

Paritas adalah jumlah anak yang dilahirkan. Paritas 2-3 merupakan paritas yang paling aman ditinjau dari sudut kematian internal paritas 1 dan paritas tinggi (lebih dari 3) mempunyai angka kematian maternal lebih tinggi. Lebih tinggi paritas, maka lebih tinggi kematian maternal. Resiko pada paritas 1 dapat ditangani dengan asuhan obstetrik lebih baik, sedangkan resiko pada paritas tinggi dapat dikurangi atau dicegah dengan ber-KB ${ }^{13}$.
Penelitian yang dilakukan ${ }^{11}$ menyebutkan bahwa paritas mempunyai hubungan yang signifikan dengan kunjungan nifas. Menurut ${ }^{14}$ paritas dapat dibedakan menjadi nullipara (wanitayang belum pernah melahirkan anak hidup), primipara (wanita yang telah melahirkan satu anak), multipara (wanita yang telah melahirkan anak kedua sampai keempat), grandemultipara (wanita yang telah melahirkan anak lebih dari empat).memiliki anak sebelumnya cenderung memiliki pengalaman dan pengetahuan yang lebih dibandingkan dengan yang baru pertama kali memiliki anak.

\section{Analisa Bivariat}

Hubungan Pengetahuan dengan Ketidakcukupan Kunjungan pada Ibu Masa Nifas di RB Mitra Ananda Palembang Tahun 2020

Penelitian lain yang dilakukan oleh ${ }^{9}$ juga mengatakan bahwa terdapat hubungan antara pengetahuan dengan ketidakcukupan kunjungan pada ibu masa nifas karena ibu yang berpengetahuan baik 1,9 kali berpeluang untuk melakukan kunjungan nifas dibandingkan dengan ibu yang berpengetahuan kurang baik.

Pemahaman tentang masa nifasdapat dibagi menjadi 2 yaitu tinggi rendahnya pengetahuan ibu yang dapat dilihat dari berapa persen ibu mengetahui tentang kunjungan masa nifas. Hal ini juga selaras dengan penelitian7yang meneliti tentan faktor-faktor yang berubungan dengan kunjungan ibu masa nifas di wilayah kerja Puskesmas Jelbuk didapatkan hasil terdapat hubungan antara pengetahuan dengan lengkap atau tidaknya kunjungan masa nifas. 
Hubungan Pendidikan dengan Ketidakcukupan Kunjungan pada Ibu Masa Nifas di RB Mitra Ananda Palembang Tahun 2020

Dari hasil penelitian didapatkan nilai $p$ value adalah 0,000 yang menunjukkan bahwa adanya hubungan yang bermakna antara pendidikan dengan ketidakcukupan kunjungan pada ibu masa nifas. Penelitian 11 juga mengatakan bahwa terdapat hubungan antara pendidikan dengan ketidakcukupan kunjungan pada ibu masa nifas, rendahnya pendidikan dan kurangnya informasi yang diperoleh dapat berpengaru terdapat kegagalan kunjungan masa nifas.

Tingkat pendidikan dan akses ibu terhadap media masa juga mempengaruhi pengambilan keputusan, dimana semakin tinggi pendidikan semakin besar peluang untuk melakukan kunjungan nifas.Tingkat pendidikan formal yang tinggi memang dapat membentuk nilai-nilai progresif pada diri seseorang, terutama dalam menerima hal-hal baru, termasuk pentingnya melakukan kunjungan nifas.

Penelitian lain yang selaras yaitu penelitian yang dilakukan oleh ${ }^{11}$ yang mengatakan terdapat hubungan antarapendidikan dengan ketidakcukupan kunjungan pada ibu masa nifas. Semakin tinggi tingkat pendidikan seseorang maka semakin tinggi membutuhkan pusat-pusat pelayanan kesehatan sebagai tempat berobat bagi dirinya dan keluarga. Dengan berpendidikan tinggi, maka wawasan pengetauhan semakin bertambah dan semakin menyadari bahwa kesehatan begitu penting bagi kehidupan sehingga termotivasi untuk melakukan kunjungan ke pusat-pusat pelayanan kesehatan ${ }^{12}$.

Hubungan Paritas dengan Ketidakcukupan Kunjungan pada Ibu Masa Nifas di RB Mitra Ananda Palembang Tahun 2020
Dari hasil penelitian yang dilakukan di RB Mitra Ananda Palembang tahun 2020 diperoleh bahwa dari 33 responden yang memiliki paritas tinggi dengan kunjungan nifas cukup yaitu sebanyak 20 responden $(60,6 \%)$ dan untuk kunjungan nifas tidak cukup sebanyak 0 responden $(0 \%)$. Sedangkan untuk paritas rendah dengan kunjungan nifas cukup yaitu sebanyak 3 responden $(9,1 \%)$ dan kunjungan nifas tidak cukup sebanyak 10 responden $(30,3 \%)$.

Adapun hasil analisa hubungan antara paritas dengan ketidakcukupan kunjungan pada ibu masa nifas dengan menggunakan uji Chi-Square diperoleh nilai $p$ value $0,000(p<\alpha)$ yang menunjukkan adanya hubungan yang signifikan antara paritas dengan ketidakcukupan kunjungan pada ibu masa nifas.

Penelitian ${ }^{11}$ menyebutkan bahwa terdapat hubungan antara paritas dengan ketidakcukupan kunjungan pada ibu masa nifas, karena semakin banyak anak yang dimiliki tentunya semakin berpengalaman bagi ibu terkait apa saja yang harus dilakukan pasca persalinan.

Paritas adalah yang membentuk pengalaman ibu dalam menjalani kehamilan. Bagi ibu primipara lebih tertarik untuk kontak ke nakes pasca bersalin untuk menanyakan proses pemulihan pada dirinya. Sebaliknya ibu multipara tidak tertarik berkunjung ke pelayanan atau tenaga medis pasca bersalin karena berpendapat telah pengalaman kemudian akhirnya merasa malas untuk kontak nifas ke tenaga medis Masa nifas ini merupakan hal penting untuk nakes khususnya bidan dalam pemantauan bayi dan ibunya karena bila kurang maksimal dapat menyebabkan ibu mengalami berbagai masalah, bahkan dapat berlajut pada gangguan/masalah masa nifas seperti sepsis puerperalis. Ditinjau melalui sisi penyebab ibu meninggal, infeksi 
merupakan penyebab ibu meninggal terbanyak nomor dua setelah perdarashan, sehingga sangat cocok bila tenaga medis memberi perhatian yang luar biasa ketika masa ini ${ }^{15}$.

\section{KESIMPULAN}

1. Distribusi frekuensi responden yang memiliki Kunjungan Nifas cukup 23responden $(69,7 \%)$ sedangkan yang memiliki Kunjungan Nifas Tidak Cukup yaitu ada 10 responden $(30,3 \%)$.

2. Distribusi frekuensi responden yang memiliki pengetahuan tinggi yaitu 23 responden $(69,7 \%)$, sedangkan kadar pengetahuan rendah yaitu 10 responden $(30,3 \%)$.

3. Distribusi frekuensi responden yang memiliki pendidikan tinggi yaitu 21 responden $(63,6 \%)$ sedangkan pendidikan rendah yaitu 12 responden $(36,4 \%)$.

4. Distribusi frekuensi responden yang yang memiliki paritas tinggi yaitu 20 responden $(60,6 \%)$ sedangkan yang memiliki paritas rendah yaitu 13 responden $(39,4 \%)$.

5. Terdapat hubungan yang signifikan antara pengetahuan dengan ketidakcukupan kunjungan pada ibu masa nifas.uji Chi-Square Serta didapatkan nilai $p$ value 0,012 Ho di tolak (hipotesis di terima).

6. Terdapat hubungan yang bermakna antara pendidikan dengan ketidakcukupan kunjungan pada ibu masa nifas berdasarkan uji Chi-Square di dapatkan nilai $p$ value 0,000. Ho Ho di tolak (hipotesis di terima).

7. Terdapat hubungan yang signifikan antara paritas dengan ketidakcukupan kunjungan pada ibu masa nifas berdasarkan uji Chi Square di dapatkan nilai $p$ value 0,000 . Ho di tolak (hipotesis di terima).

\section{SARAN}

a. Bagi peneliti selanjutnya

Pada peneliti selanjutnya diharapkan dapat melakukan pengembangan penelitian tentang faktor-faktor yang mempengaruhi kunjungan pada ibu nifas dengan referensi yang lebih banyak atau dengan metode lain yang belom diteliti sebelumnya.

b. Bagi Tenaga Kesehatan

Diharapkan dapat memberikan informasi kepada ibu nifas bahawa kunjungan nifas itu dilakukan 4 kali kunjungan untuk mengetahui derajat Kesehatan ibu dan bayi.

\section{DAFTAR PUSTAKA}

1. Elizabeth. Siswi, W. \& Endang, P. (2015). Asuhan Kebidanan Masa Nifas dan Menyusui. Yogyakarta: Pustaka Baru Press

2. Widyasih. 2013. Asuhan Pada Masa Nifas. Yogyakarta: Salemba Medika

3. Kemenkes RI, 2015. Riset Kesehatan Dasar. Jakarta

4. Dinkes Palembangprofil kesehatan 2017

5. Bahiyatun. 2015. Buku Ajar Asuhan Kebidanan Nifas Normal. Jakarta: EGC

6. Prawirohardjo. 2009. Ilmu Kebidanan. Jakarta: Bina Pustaka Sarwono, Prawihardjo

7. Rahmawati, A. 2015. Perawatan Nifas. Yogyakarta: Fitramaya

8. Notoatmodjo, S. 2010. Metodelogi Penelitian Kesehatan. Jakarta: Rineka Cipta

9. Ibrahim, C. S. 2012. Perawatan Kebidanan. Jakarta: Bharata Niaga Media

10.Notoatmodjo, S. 2012. Metodelogi Penelitian Kesehatan. Jakarta: Rineka Cipta

11. Herlina, S. 2011. Hubungan Karakteristik dengan Tingkat Pengetahuan Ibu Postpartum tentang Perawatan Masa Nifas di Ruang Camar I Rumah Sakit Umum Daerah Arifin Achmad Pekanbaru Tahun 2009. Universitas Sumatera Utara.

12.Mirzal, M. 2008. Panduan Lengkap Kehamilan. Yogyakarta: Kata Hati

13.Winkjosastro, H. 2007. Ilmu Kandungan. Jakarta: Yayasan Bina Pustaka Sarwono Prawirohardjo.

14.Saifuddin. 2012. Asuhan Kebidanan 4 Patologi. Jakarta: Trans Info Medika

15.Anggraini, Y. 2010. Asuhan Kebidanan Masa Nifas. Yogyakarta: Pustaka Rihama 